\title{
DECODING SCALE AND SIZE OF THE ACQUIRED AND THE ACQUIRER: AN EMPIRICAL ANALYSIS
}

\author{
Raghawendra Kumar \\ Research Scholar, Department of FMS, MRIIRS (Deemed-To-Be-University), Faridabad, \\ Haryana, India \\ Dr. Meghna Chhabra \\ Associate Professor, Department of FMS, MRIIRS (Deemed-To-Be-University), Faridabad, \\ Haryana, India
}

\begin{abstract}
Purpose: Corporate performance is measured in terms of financial parameters. Firm 's operations always aimed towards achieving financial and other goals and fulfilling shareholder's expectations. Growing organically is the test of patience which firm 's can hardly afford to, particularly in the light of sword-edged competition. Mergers and Acquisitions provide an inorganic tool which helps firms to race against time to achieve their objectives. The prime focus of this paper is to identify the determining characteristics that distinguishes Acquirers from Targets, and provide evidence to demonstrate whether firms are likely to be the acquirers or the targets.
\end{abstract}

Methodology: Ratio analysis approach has been applied to judge level and scale of financial parameters taken from 3 broad categories namely, liquidity ratios, profitability ratios and capital structure ratios. Normality test was done by calculating mean, median, standard deviation, kurtosis and skewness by descriptive method as well as by $K-S$ and $S$ - $W$ test. Data was found to be non-normal, therefore, application of nonparametric test was found to be more appropriate to analyse data of 20 sample firms. Statistical tools used to perform data analysis and hypothesis testing were: Mann Whiteney U-test, Two sample K-S test and Wilcoxon Signed Rank test. Correlation was performed to do proximity-test between acquirer and target.

Findings and conclusions: Hypothesis testing at $5 \%$ significance level provided evidence to conclude that Acquirers and Targets differ from each in terms of profitability only. There was no difference in liquidity position and Capital Structure position between acquirers and targets. Therefore, the study did not find any characteristic difference between acquirers and targets so far as Liquidity and Capital Structure position is concerned.

Research Limitations: Only domestic mergers were taken as sample and size of sample was also small, making the generalization of outcomes rather limited. 
Generalization of outcomes may become more broad and wide in scope and more conclusive if further researchers employ large sample for analysis.

\section{Type: Research Paper}

Value: This research paper is original in content and has not been published or produced anywhere and on any literary/academic platform.

Key words: Corporate performance, Financial parameters, Mergers and Acquisitions, Organically, etc.

Cite this Article: Raghawendra Kumar and Meghna Chhabra, Decoding Scale and Size of The Acquired and The Acquirer: An Empirical Analysis, International Journal of Management, 11(12), 2020, pp. 1205-1230.

http://iaeme.com/Home/issue/IJM?Volume=11\&Issue=12

\section{INTRODUCTION}

With new economic policy in 1991, all restrictions relating to M\&As and licensing were taken away because these restrictions were directly or indirectly creating a road blocks for competitiveness and economic expansion. MRTP Act repealed in the same year. FERA restriction related to borrowings from abroad were also eased in 1993. Private players including MF and FIIs were given nod to enter Indian capital market (Companies News and Notes, 1993). FEMA which came into existence in 2000, allowed 100\% investment in the proceeding of ADR/GDR. The certain changes introduced in 2005 permitted Indian Inc to invest up to $200 \%$ of their Net Worth unconditionally (Gopinath, 2007:237). The developing countries that have enacted anti monopolistic law have increased from 35 in 1995 to 100 in 2003 (CUTS 2003 as cited in Ramaswamy, 2006 2006). With the enactment of CCI Act, various anti-concentration measures were undertaken to ensure fair competition. The act permitted mergers and consolidations subject to the condition that they do not violate competition law. All M\&A deals having the combined turnover worth more than Rs. $3000 \mathrm{cr}$. or combined assets worth more than Rs. 1000 cr. will be referred to competition commission (The Gazzet of India, 2003). As per SEBI regulations in 1994 (revised in 1999), the acquirer has to appoint a registered merchant banker before M\&A deal is announced in the public domain. No any consolidation programme can be taken without limit and Competition Commission of India does not specify any restriction regarding market size. It provides abundant scope of misuse of power of dominance by big fish (Chandrashekhar, 2003). During second half of 1990`s majority of M\&A acts were in the sectors with related management (Agarwal, 2003). So far as merger activities in consumer industries is concerned, $40 \%$ of deal involved buying out of local units by the MNCs (Kumar, 2000: Saha, 2001).

M\&As gained momentum in 1990s, although in other developing, countries it had started in second half of $19^{\text {th }}$ century. The world was waiting to grasp the opportunity created by technological innovations followed by new political-economic regime heralded through three pillars of privatization, liberalization and globalization (UNCTAD 2000). The significant aspect of Indian economic development is that cross-border M\&A dominated the merger activity wherein $40 \%$ of FDI inflows came through cross-border mergers (Beena 2001b; Saha, 2001). Many MNCs took advantage of ill-conceived financial reforms and structural mismanagement during post liberalization phase (Khanna, 1999), and also due to higher interest rate (Basant and Morris, 2008). Kumar (2000) opined that such activities have adversely affected the process of capital formation, the situation of balance of payments, the transfer of technology and of course, the competition environment. The responsible factor for Indian corporates acquiring foreign ones may be the acquisition of advanced technology; becoming global leaders; seeking export arenas and creating big structure (Nagraj, 2006; Nayyar, 2007). 
World economic environment has been alarmed due to pace of globalization and innovation in technology and corporates are finding it difficult to deal with the situation organically and they are compelled to go inorganic way. In the USA between 1996-2001, company`s bosses inked acquisition deals almost every hour every day (Dyer, Kale and Singh,2004). Merger wave of 1995 to 2000 led to deals worth \$12 trillion and more (Selden and Colvin, 2003). The schools of merger theory classified it on the basis of capital market valuation and on empire-building motives. The inefficient firms are most likely to be the target of acquisition owing to the gains derived by the acquirers (Manne, 1965). The factors that enhances wealth of firms goes for M\&A because of : (a) Efficiency enhancement through economies of scale, (b) Searching for asymmetric information and taking advantage of it, (c) Providing solutions of agency problems, (d) Increasing market share, and (e) Availing tax benefits. The other factors that cause financial inducements include; avoiding indebtness, increasing leverage, etc,. Shareholders wealth maximization theory advocates that firms go for M\&A only when deals result in positive NPV when calculated on discounted cash flow basis. The new managerial theory prefers to increase shareholdings and control and it induces management to maximise their own self-interest (Peel, 1995). Jensen and Ruback (1983) in their study found that managers compete for more control over resources through M\&As. Wasserstein (1998), in his book on M\&A comes out with five main motives of merger: regulated environment and political-economic reforms, technological advancement, spurt in financial markets, the leadership, and scale vs focus approach. In $40 \%$ of all acquisitions, the bidder's stock prices falls just after a deal's announcement (Bruner, 2004). The investors had doubts in their mind about where acquirer will be able to maintain their original and perceived values post- merger and unfavourable market response further aggravated their doubts. Most of merger benefits were realised by the bidder immediately after announcement if any (Severiess,1991). The size of firms too matters and have effect on merger activities but depends upon the respective needs of different organisations (Harris,et al., 1982). The different models suits to different motives. Depending upon studies to be investigated and characteristics of merging firms different researchers came out with their own models such as: multivariate discriminant analysis, model of Simkowitz and Monroe and Ssimowitz (1971), Seven (1973) and Binary logit model of Dictrich and Sorensen (1984). All These models use secondary data available on websites of acquired and acquirer firms.

The recent merger waves created in India is similar to re-discovery of India by world corporates (Pilania 2008, SE-Editorial). The world sees abundant opportunities in economic spheres in India but it also poses peculiar challenges. These challenges need guided thoughts and action by MNCs if they intend to serve Indian market (Pilania, 2008 SE-Editorial). Favourable govt. policies and unanimity of political establishments, followed by dynamic entrepreneurs and abundant financial opportunities and scope, are the driving force in Indian M\&A trends (Amano, 2009).

\subsection{International $M \& A$, a recent phenomenon}

The latest trend in Indian M\&A activities is that the Indian corporates are acquiring foreign companies particularly in sectors like IT and ITES, although other sectors are not lagging behind much. The Indian corporates are increasingly getting involved in global economic activity, which further accelerated the pace of M\&A activity in India (W. Chie, 2008). The deal value increased at a rate of $28.3 \%$ between 2000 and 2007 which involved cross-border M\&A to reach US \$22.6b (Accenture and CCI, 2008). The foreign companies are getting stiff competition in India and more often than not they are getting thrown away continuously (Accenture, 2006). The main motivating factors responsible for increased merger activities includes, operational synergy, access to international market, search for technology, and saturating Indian market potential. The firms in manufacturing sector were still dominantly searching for export (Pradhan and Abraham, 2005). 
Trautwein (1990) has listed seven theories of merger motives that includes efficiency theory, process theory, raider theory, and disturbance theory among others. Cross-border mergers pursue the motives of becoming international that results in more and more companies becoming global (Buckley and Casson, 1976). Johanson and Vahlne (1977) opined that more and more firms trying to access international market. They usually starts with exports and then set up their own manufacturing facilities. Luo and Tung (2007) stated that newly emerging MNCs showed more intensely to internationalize since they entered into this field quite late.

According to Athukrola (2009), Birla group were first Indian corporate to inter into international market through ventures in Ethiopia in 1959 followed by venture in Kenya in coming year. Initially they went for Joint-Ventures and started subsidiaries abroad. In post liberalization phase there was spurt in M\&A activity and in the period of 2007-2010 more and more purchases were conducted (Reddy, 2015b). This trend was due to lower valuation of assets in international markets than in domestic market (Ready et al., 2014). A recent study shows search for market, search for resources and gaining efficiency happened to be the major motives of mergers (Laura et al., 2015).

Many studies investigating into post M\&A impact, however, conclude that there are not many benefits to be derived from M\&As, (Berger and Humphery, 1992; Peristiani, 1997; Pilloff and Santomero,197; Rhoades, 1998; Cummins et al., 1999; and Cabanda and Pascual, 2007).

\section{THEORIES OF M\&A; WHY FIRMS MERGE?}

Harris et al (1982) summarised merger motive theories into two: Maximisation of Values theory and Building of Empire theory. Writing for market for control hypothesis believes that targets can be predicted using accounting data. Many studies (Singh,1971; and Tsagkanos et al., 2006) proposed hypothesis testing to identify target firms which are inefficient. Following are important theories dealing with merger motives:

\subsection{Theories on Motives and Implications of M\&A}

There is always a particular motive behind M\&As. The traditional literature also support merger motives as pro-active and defensive. The pro-active theory is related to gaining market power whereas the later one provides for safeguarding organization`s existing interests (Cantwell and Santangelo, 2002).

\subsubsection{Mergers as a tool to increase efficiency}

The vertical mergers create a collective structure by combining the value chains by mutual agreement and confidence which ultimately increase efficiency (Williamson, 2002). Coase (1937) judges the efficacy of integration particularly when firms are finding it difficult to transact among themselves. More often than not, firms are uncertain about their future happenings (Bolton and Schartstein, 1998;97). Alternatively, it can be said that mergers may also result in inefficient outcomes as against the supposed efficient outcomes derived from aggressive bargaining that occurs in the Grossman-Hart-Moore paradigm (Bolton and Schartstein, 1998;111). Vertical mergers increases control over inputs, may cut duplication cost of research, may rationalize marketing and distribution channels and more (Coase, 1937; Ansoff and Weston,1962). Schemalensee (1987) is of the opinion that cost cutting effect is more evident in M\&A than synergy. Williamsos (1968) comes out with the result that gains from increased market power of firms often result in price rise over and above the what competition warrants. 


\subsubsection{Mergers as a tool to increase monopoly}

Mergers not only reduces the number of firms but also creates barriers for new entry. If mergers results in product differentiation either through patents or through significant improvement, it can create artificial barrier also. The Chicago school of thought advocates that mergers is better than involving firms into price wars (Bhattacharjea, 2000). The mergers act allows firms to increase control through empire-building which ultimately reduces their likelyhood of becoming target of takeover by others (Beena 2001a; Singh 2003). Despite availability of antimonopoly regulations monopolistic tendencies still exist in liberalized environment even today (Singh 1999; Evenett 2002). Grossman and Hart (1986) and Hart and Moore (1990) were of the views that increased ownership would result in residual control over physical assets by the owners unless and until prohibited otherwise (Bolton and Schartstein 1998;98). Berle and Means (1932) opined that divorce between ownership and control may induce managers to pursue their own goals and not of owners.

The motive of international mergers may be to take advantage of access to cheap raw materials, cheap labours and to benefits from favourable exchange rate mechanism (Weston et al., 1996). Horn and Persson (20010) study finds lower transaction cost and not the tariff benefits that drives international mergers. Lommerud et al., (2005) was of the view that international mergers creates oligopolistic market which happen to be plant specific unionised. Decrease in wage rate makes the international mergers profitable in unionised specific industries. Neary (2004) came to the conclusion that difference in cost of technology makes low cost technology firms acquiring firms with high cost technology in international markets. Qui and Zhou (2006) showed how mergers increase consumer surplus and ensure welfare of society if products are differentiated in post- merger phase. The above study also demonstrated that that international merger is although unprofitable, yet socially desirable. On the basis of linear/Cournot framework, Bhattacharjea (2003) opined that mergers should intend to increase in export otherwise it will reduce social gains. The international mergers aims at increasing competitiveness by diversifying operations and integrating structures (Cantwell and Santangelo, 2002). Sanjaya Lal (2002) questioned whether benefits outweighs related concerns of mergers. The real benefits of mergers depends upon specific circumstances in respective countries and the marketing strategy of MNCs (Dunning, 1993). The mergers may reduce competition if anti-monopolistic measures does not exist in any country with shrinking demands (Zhan and Ozawa, 2001).

\subsubsection{Mergers as a tool of Macro-economic changes}

Merger is done to adjust, accommodate and fill the gaps in demand and supply as well as inadequacy in technology (Post,1994; Wesonet et al.,1996). Voluminous size is main motive of merger as against financials, as it helps protecting firms from being takeover targets (Singh,1975). Andrade, Mitchell and Strafford (2002) opined that the deregulation of economy induced merger activities in the US during 1990's. On the other hand, major Industrial shocks led by big corporate scandals resulted in large scale mergers (Mitchell and Mulherin,1996). Integrating economy of Europe with the formation of EU and the formation of NAFTA (Caves, 1991; UNCTAD 1997) further led to spurt in merger activities.

\subsubsection{Mergers as a tool to achieve Financial objectives}

If opportunity to grow organically becomes less attractive then firms go for inorganic way, ie., they resort to M\&As. Earlier, internal resources were employed for acquisition activity which was limited to big corporates but now different sources of external capital is available making cross-border mergers easy and accessible to all big or small (Sudarsanam,1995). Differing values of share prices and economic upheavals has made low value firms a soft target for 
acquisition (Gort, 1969). Decrease in interest rates has further helped firms to borrow and acquire (Melicher et al.,;1983). Devaluation of dollar as compared to Pound and Yen was chiefly responsible for British and Japanese firms acquiring the US firms in early 1980s (Dunning, 1993). The countries affected by economic crisis generally devalue their currencies in order to increase export, that lowers the acquisition cost of assets by MNCs to enter local markets (Zhan and Ozawa,2001). Hay and Liu (1998) found that important role played by fundamental economic variables justifies the growth of acquisition similar to free-cash flow hypothesis of Jensen (1988). Beena (2001a) in her study showed that the financial motives was the main driver of mergers in early 1990s in India. The firms main objective was to strengthen the financial position by restructuring capital structure. Sweezy (1994) found that super structure grew but they did not improve productive capacity too much. However, there is no direct link establishing super structure and achieving financial objectives through mergers with present level of research.

\section{LITERATURE REVIEW}

\subsection{On Determinants or motives of M\&As}

The main strategies of firms is to increase sustained revenue and consolidate market share, and for that they comes out with innovative products and exploring new markets. This is what we call the organic way. On the other hand if the internal measures are found to be inadequate they resort to external growth through M\&As

The research studies on many M\&As in India in last decade (Basant,2009; Beena,2001 and 2004; and Agarwal,2002) tried to find out trends and motives of M\&A in India without adopting any particular methodology. In their study, Agarwal and Sensarma (2007) identified two dependent variables as occurrence of event (merger) and the number of events (mergers) that took place between 2002 and 2004 in India by using regression model. They found availability of growth opportunities and availability of free-cash as important determinants of consolidations. Harris et al.,(1982) in their studies tried to find out characteristics differences between acquirers and acquired by using Probit analysis of firms from US and UK. They used certain financial parameters such as profitability, liquidity, tax benefits, MPS, EPS, among others to find determinants of M\&As. They come out with the conclusion that low P/E ratio makes firms easy target of takeover. Thompson (1997) finds out smaller asset size, small retained earnings, among others as important determinants of takeover while analysing mergers activities in the Building Societies of UK (1981 to 1993). Worthingon (2004) was of the opinion that firms with low diversification happened to be soft target of acquisition. Sanfilippo et al.,(2008) propounded that firms with high loan percentage in capital structure are easy targets. In few studies total employees strength was considered to indicate size of the firms (Nguyen and Ollinger,2006) to be the determining factor of acquisition.

Research finding by Bhalla (2011) supports the market for control hypothesis as a major determinants of acquisition. According to this paper, firms with greater size, better capital position and management of asset turned out to be acquirer.

According to Berkovitch and Narayanan (1993) synergy happened to be the main motive in most of the successful mergers whereas in most of the failed mergers agency problems dealing with management was the important motive. Logit binary regression model was used by Meador, Church and Rayburn (1996) to identify factors to foresee M\&A targets. The horizontal integration model had predicted more accurately the targets with variables long term debt/total assets, long term debt/market value, market value/book value and asset growth and sales growth showing significance. Barnes (1990) used MDA analytical techniques to predict the targets. He came out with conclusion that industrial financial ratio gives accurate prediction in his survey of UK firms. 
Zanakis and Zopounidis (1997) also used ratio analysis in his study of Greek firms between 1983 and 1990 and concluded that ratios had limited ability to predict merger targets with exception of leverage ratio which was found to be the significant factor. Owen (1995) used logit regression model to analyse the characteristic features of acquirer and the targets and came out with outcome that age is an important factor. He concludes that younger firms are the most likely targets even though they had the potential to become vibrant in future. He found high $\mathrm{P} / \mathrm{E}$ ratio of target firms indicating market had positive expectations from them. Sorensen (2000) on the other hand, in his study of merged, merging and non-merging firms, finds financial ratios not very significant indicator of mergers and acquisitions. Merging firms had to rationalize their structure and processes in order to achieve desired outcomes (Mani, 2009).

Jhunjhunwala (2010) in his study of M\&A in telecommunication industry revealed that acquisitions helped in bringing down prices due to increased competition but could not make them viable enough to sustain. CCI is very cautious in approving mergers and clear merger proposals only when it is supposed to help them becoming efficient and strengthening their R\&D. Evidence from developed market suggest that regulatory norms does help in ensuring competitiveness and strengthening markets for benefits of consumers who are the ultimate stakeholders (Deora, 2011).

Berkovitch and Narayanan (1993) found synergy, agency and hubris as three important motives of takeover, out of them synergy was the major indicator. Agency motive only helped in decreasing the value of acquisitions. According to hubris hypothesis, managers erred in target selection leading to no synergy. Seth et al., (2000), in their study of acquisition of foreign firms by US firms found synergy as a major motivator. The study also suggested the presence of hubris as motivator. Different studies differ not only in approach but also in their outcomes. Approaches and outcomes vary from industry to industry. Warf (2003) found telecom industry of US and Europe highly consolidated because of globalization, increasing scope and scale post mergers. Koi-Akrofii (2014), in his study found synergy, growth, market positions and tendency of managers for empire-building respectively, as major motivators of M\&As in Telecom industry.

Exploration and exploitation are the other two motivating factors found in the literature of recent studies used in organizational learning (March, 1991). Exploration simply means searching for new products, markets and technology and is very risky, whereas exploitation implies selecting implementing and executing a plan of action with respect to M\&A. March (1991) suggests for a balancing act for choosing between the two in order to achieve the desired outcomes. Wright et al., (2005) was of the opinion that firms in newly emerging economies acquired foreign firms by mostly adopting exploration strategy.

A study by Ngueyen et al., (2012) consisting of 3520 domestic acquisitions as a sample, found indecisive outcomes because they found many mergers created value for their shareholders but in many cases mergers actually led to destruction of values of shareholders wealth. Wang and Moini (2012) in their study of M\&A of Danish firms, found geographical expansion, product expansion, rapid growth, achieving economy of scale and scope, acquiring updated technology among others, as key motivating factors of mergers. A recent study by Rani et al., (2012) found operating synergy as major driving factor of mergers. Srivastava, (2012) in his research of M\&A in pharmaceutical industries in India concludes that mergers helps firms to consolidate market standing, earning quick returns and strengthening position in local market.

\subsection{Review of literature on cross-border M\&A}

According to Reddy (2015c), cross-border mergers links a local industry with world economy, and together with strong internal mechanism decides the exchange rate in favour of local 
industries which further helps firms to internationalize. The way to Internationalization has been given by OLI paradigm by Dunning $(1997,1988)$, according to which firm must have ownership advantages $(\mathrm{O})$, location advantages (L) and internationalization (I) to became a MNC. Dunning et al., (2008) through his series of research study come out with a list of motivating factors. They say that the initial motive of Indian firms going for mergers were to gain access to international market and avoid domestic rigorous regulations. However, recently they are focussing on acquisition of latest technology and acquiring international brands. Sun et al., (2012) with the objective of coming out with the factors driving mergers of foreign firms by Indian firms, list five characteristic features that creates comparative ownership advantages for Indian firms, namely-industry related factor; dynamic learning; value creation; restructuring value chain; and industrial facilitation and constraints. This theory which considers five characteristics providing strategic advantage to domestic firms was applied to study acquisitions of cross-border firms by Indian and Chinese firms.

\subsection{Literature review based on characteristics differences between acquirer and the acquired}

Early analysis (Altman, 1968; Beaver, 1967) using financial ratios tried to relate ratios with firms susuptible of becoming takeover targets. Many studies have build-up models to predict whether firms are target of takeovers or not A book on M\&A by Kumar and Rajiiv (2007) stated that size and liquidity position matter in deciding whether a firm can be a target or not. According to them larger size helps firms getting immunity against being taken over whereas firms facing liquidity crunch are more likely to become a soft target of takeover. Trahan and Shawky (1992) study concluded that uneven or abnormal returns on assets is another important industrial factor that matters in M\&A activity. Nunnenkamp et al., (2012) study found location as important determinant of outbound FDI (OFDI) and concludes that if firms lie in neighbouring boundaries then it impact outbound FDI favourably. The same study did not find impact of availability of raw material and availability of advanced technology on OFDI. Gubbi et al., (2010) on the other hand states that Indian firms realised greater increase in merger benefits if it acquired firms located in developed countries with advanced institutional setup. According to them non-manufacturing sectors outperformed their manufacturing counterparts in terms of financial returns. The manufacturing sector went for mergers to seek increased efficiency whereas non-manufacturing sectors were governed by other motives, particularly by non- efficiency seeking motives (Farole and Winkler, 2014). In another research by McDougall and Round, (1984), it was found that firms in industries led by advanced technology realised higher returns than other industries where advanced technology is not required. In another study by Sinha and Srinivasan, (2010) age of firms together with motivation for internationalization were found to be significant determinants of M\&As. Higher the age higher the realised financial benefits in periods following mergers (Gubbi et al., 2010; Sinha and Srinivasan, 2010).

\subsection{Literature Review based on post-merger financial performances}

Domestic firms acquire foreign firms with the objectives of achieving several intended benefits which may not come instantly but creates values to the shareholders ultimately. The intended benefits may include synergy, economic value addition and most importantly post-merger integration of production, management and Research and Development. A failed merger is sometimes an outcome of HRM and organisational issues (Bryson, 2003) if intended integration does not take place.

A study by Healy et al., (1992) showed that it was asset productivity and not the decreased labour cost that helped firms improves post-merger financials. Expenditure on R\&D also did 
not help firms in improving cash-flow. Moeller and Schlingemann, (2005) comes out with unique results. He finds that US firms did not find any improvement in their operating performances when they acquired foreign firms. On the other hand US firms undergoing domestic acquisitions improved their operating performances in comparing to outbound mergers. Maartynova and Renneboog, (2006) in their study on merged and non-merging firms concluded that both target and acquired firms performed better than those who did not merge. They further conclude that payment mode of acquisition, diversification and geographical limit did not have any significant impact on profitability of merging firms. Mantravadi and Reddy, (2008) in their studies on mergers concluded that there was the highest decline in operating performances of firms undergoing horizontal merger in domestic M\&As in India. Tripathy and Lamba, (2015) conclude that Indian firms acquiring foreign firms witnessed greater decline in profits in case when target firms belonged to developed economy. Motive of Exploration by firms seeking resources and strategic quality assets witnessed high abnormal returns (Sinha and Srivastava, 2010), while firms seeking new markets also achieved higher returns if not a very high abnormal return. seeking acquisitions provided higher returns (Gubbi et al., 2010).

\section{RESEARCH METHODOLOGY}

\subsection{Research questions and Objectives}

On the basis of literature reviews following research question arises:

- Do the firms who are target, differ significantly from acquirer firms in terms of liquidity position?

- Do target firms differ from acquirer in terms of profitability indexes?

- Do Target firms have different capital structure from acquirer firms?

Research questions directs the research work to achieve following objectives:

- To study similarity/ dissimilarity of liquidity position of acquirers and targets.

- To study similarity/ dissimilarity of profitability position of acquirers and targets.

- To study whether capital structure of acquirers and targets vary or not.

\subsection{Hypothesis}

Taking into consideration of research objectives, the following hypothesis have been formulated and tested.

H01: There is no difference between liquidity position of acquired and target companies.

H02: There is no difference between profitability position of acquired and Target companies.

H03: There is no difference between capital structure of acquired and target companies.

\subsection{Research Design}

The research design selected for this study is descriptive and analytical because this research is based on secondary data. Non-probability sampling techniques had been used to decide the sample size.

\subsection{Data collection}

Data regarding sample firm's financial ratio had been collected from moneycontrol.com for listed companies and calculated manually for non-listed companies from last reported financial statement and profit and loss account. For non-listed companies (mostly the target firms), financial ratios had been calculated manually with the help of financial statements auditors 
report and directors report for last financial year. Companies in the sample has been selected from Grant Thornton annual deals report of various years.

Selection criteria: Firms went for M\&A between 2016 and 2019 had been selected as sample. Deal size greater than or equal to 20 M USD had been considered.

Duration of study: Financial ratio of last reported financial data by companies one year before merger has been taken for study.

Sampling frame: Only domestic acquisition (50\% or more share acquisition), which excludes PE investment and start-up acquisition, subject to availability of financial data, had been consider for deciding sample size.

Sample Size: 20 acquisition deal had been finalized for sample [20 acquirer v/s 20 target].

Table (1) contains list of sample firms that went for mergers and acquisitions from year 2017 to 2019, along with deal value in US Dollar and percentage of stakes acquired by acquiring firms.

Table 1 Table of samples

\begin{tabular}{|c|c|c|c|c|c|}
\hline ACQUIRER & TARGET & SECTOR & $\begin{array}{l}\text { USD } \\
\text { (VALU } \\
\text { E) }\end{array}$ & $\begin{array}{l}\text { \% } \\
\text { STAK } \\
\text { E }\end{array}$ & $\begin{array}{l}\text { YEA } \\
\text { R }\end{array}$ \\
\hline HDFC Ltd. & $\begin{array}{l}\text { Apollo Munich Health Insurance } \\
\text { Co. Ltd. }\end{array}$ & $\begin{array}{l}\text { Banking and } \\
\text { financial services }\end{array}$ & 195.19 & $51 \%$ & 2019 \\
\hline $\begin{array}{l}\text { Sundaram Finance } \\
\text { Ltd. }\end{array}$ & $\begin{array}{l}\text { Sundaram BNP Paribas Home } \\
\text { Finance Limited }\end{array}$ & $\begin{array}{l}\text { Banking and } \\
\text { financial services }\end{array}$ & 144.88 & $50 \%$ & 2019 \\
\hline $\begin{array}{l}\text { Credit Access } \\
\text { Grameen Ltd. }\end{array}$ & Madura Micro Finance Ltd. & $\begin{array}{l}\text { Banking and } \\
\text { financial service }\end{array}$ & 123.38 & $100 \%$ & 2019 \\
\hline India Grid Trust & $\begin{array}{l}\text { Sterlite Power Transmission } \\
\text { Limited - } 5 \text { electricity } \\
\text { transmission assets }\end{array}$ & $\begin{array}{l}\text { Energy and natural } \\
\text { resources }\end{array}$ & 1660.00 & $100 \%$ & 2019 \\
\hline Adani Power Ltd. & GMR Chhattisgarh Energy Ltd. & $\begin{array}{l}\text { Energy and natural } \\
\text { resources }\end{array}$ & 511.59 & $100 \%$ & 2019 \\
\hline Adani Power Ltd. & $\begin{array}{l}\text { Essel Green Energy Pvt. Ltd. - } \\
\text { ( } 205 \text { megawatt (MW) solar } \\
\text { energy assets) }\end{array}$ & $\begin{array}{l}\text { Energy and natural } \\
\text { resource }\end{array}$ & 183.10 & $100 \%$ & 2019 \\
\hline Tata Steel Ltd. & Bhushan Energy Ltd. & $\begin{array}{l}\text { Energy and natural } \\
\text { resources }\end{array}$ & 166.23 & $100 \%$ & 2019 \\
\hline $\begin{array}{l}\text { Radiant Life Care } \\
\text { Pvt. Ltd. }\end{array}$ & Max Healthcare Institute Ltd. & $\begin{array}{l}\text { Pharma, healthcare } \\
\text { and biotech }\end{array}$ & 300.86 & $50 \%$ & 2019 \\
\hline $\begin{array}{l}\text { Dhanuka } \\
\text { Laboratories Ltd. }\end{array}$ & Orchid Pharma Ltd. & $\begin{array}{l}\text { Pharma, healthcare } \\
\text { and biotech }\end{array}$ & 161.74 & $100 \%$ & 2019 \\
\hline Havells India Ltd. & $\begin{array}{l}\text { Lloyd Electrical and Engineering } \\
\text { Ltd. Consumer durables business } \\
\text { unit under the brand Lloyd }\end{array}$ & Manufacturing & 235.29 & $100 \%$ & 2017 \\
\hline $\begin{array}{l}\text { Oil and Natural Gas } \\
\text { Corporation Ltd }\end{array}$ & $\begin{array}{l}\text { Hindustan Petroleum Corporation } \\
\text { Ltd }\end{array}$ & $\begin{array}{l}\text { Energy and Natural } \\
\text { Resources }\end{array}$ & 5,780 & $51 \%$ & 2018 \\
\hline $\begin{array}{l}\text { Adani Transmission } \\
\text { Ltd }\end{array}$ & $\begin{array}{l}\text { Reliance Infrastructure Ltd - } \\
\text { Mumbai power business }\end{array}$ & $\begin{array}{l}\text { Energy and Natural } \\
\text { Resources }\end{array}$ & 2938 & $100 \%$ & 2018 \\
\hline $\begin{array}{l}\text { UltraTech Cement } \\
\text { Ltd }\end{array}$ & $\begin{array}{l}\text { Century Textiles and Industries } \\
\text { Ltd Cement Business }\end{array}$ & Manufacturing & 1,306 & $100 \%$ & 2018 \\
\hline
\end{tabular}


Raghawendra Kumar and Meghna Chhabra

\begin{tabular}{|l|l|l|l|l|l|}
\hline Bandhan Bank Ltd. & Gruh Finance Ltd & Financial Services & 3000 & $100 \%$ & 2019 \\
\hline $\begin{array}{l}\text { Muthoot Finance } \\
\text { Ltd. }\end{array}$ & IDBI Asset Management Ltd. & $\begin{array}{l}\text { Banking and } \\
\text { financial services }\end{array}$ & 30.28 & $100 \%$ & 2019 \\
\hline $\begin{array}{l}\text { Muthoot Finance } \\
\text { Ltd. }\end{array}$ & IDBI MF Trustee Company Ltd. & $\begin{array}{l}\text { Banking and } \\
\text { financial services }\end{array}$ & 30.28 & $100 \%$ & 2019 \\
\hline $\begin{array}{l}\text { DSM India Pvt. } \\
\text { Ltd. }\end{array}$ & $\begin{array}{l}\text { SRF Ltd. - engineering plastics } \\
\text { business }\end{array}$ & Manufacturing & 45.60 & $100 \%$ & 2019 \\
\hline $\begin{array}{l}\text { Grasim Industries } \\
\text { Ltd. }\end{array}$ & $\begin{array}{l}\text { KPR Industries (India) Ltd. - } \\
\text { chlor-alkali business }\end{array}$ & Manufacturing & 35.63 & $100 \%$ & 2019 \\
\hline $\begin{array}{l}\text { Spencer's Retail } \\
\text { Ltd. }\end{array}$ & Nature's Basket Limited & Retail and consumer & 42.76 & $100 \%$ & 2019 \\
\hline \begin{tabular}{l} 
Birla Corp. Ltd \\
\hline
\end{tabular} & $\begin{array}{l}\text { Reliance Cement Company } \\
\text { Private Limited }\end{array}$ & Manufacturing & 710.00 & $100 \%$ & 2016 \\
\hline
\end{tabular}

Source: Compilation from Grant Thornton Annual Deal Tracker 2017,2018,2019, 2020.

Table (2) contains list of financial ratios along with definition of parameter ratios and formulae used to calculate these ratios.

Table 2 Defining Financial Parameters

\begin{tabular}{|c|c|c|c|}
\hline \multirow[t]{3}{*}{$\begin{array}{l}\text { Liquidity } \\
\text { ratio }\end{array}$} & CUR & $\begin{array}{l}\text { Current ratio demonstrate how } \\
\text { liquid the firm is. It shows the } \\
\text { ability of firm to meet its current } \\
\text { liability from current assets. } \\
\text { Higher the ratio higher is the } \\
\text { firms liquidity. }\end{array}$ & Current Ratio $=\frac{\text { Current Asset }}{\text { Current Liability }}$ \\
\hline & CR & $\begin{array}{l}\text { Cash ratio shows the firm's } \\
\text { ability to meet the current liability } \\
\text { from available cash or cash } \\
\text { equivalent }\end{array}$ & Cash Ratio $=\frac{\text { Cash }+ \text { Marketable security }}{\text { Current liability }}$ \\
\hline & QR & $\begin{array}{l}\text { Quick ratio also called acid test } \\
\text { ratio shows the ability of firms to } \\
\text { meet short term liabilities from } \\
\text { most liquid assets excluding } \\
\text { inventories and other current } \\
\text { assets. }\end{array}$ & $\begin{array}{l}\text { Quick Ratio= } \\
\frac{\text { Current Asset-inventory-other current asset }}{\text { Current liability }}\end{array}$ \\
\hline \multirow[t]{3}{*}{$\begin{array}{l}\text { Profitability } \\
\text { ratio }\end{array}$} & GPM & $\begin{array}{l}\text { It shows the excess of sales over } \\
\text { cost of goods sold. }\end{array}$ & $\mathrm{GPM}=\frac{\text { EBIT }}{\text { Sales }} * 100$ \\
\hline & NPM & $\begin{array}{l}\text { It is profit available to } \\
\text { shareholders after meeting all } \\
\text { direct and indirect expense. }\end{array}$ & $\mathrm{NPM}=\frac{\text { PAT }}{\text { Sales }} * 100$ \\
\hline & EPS & $\begin{array}{l}\text { Earning per share is net return to } \\
\text { each shareholders. }\end{array}$ & $\mathrm{EPS}=\frac{\text { PAT }}{\text { Sales }} * 100$ \\
\hline \multirow[t]{2}{*}{$\begin{array}{l}\text { Capital } \\
\text { structure } \\
\text { ratio }\end{array}$} & $\mathrm{D} / \mathrm{E}$ & $\begin{array}{l}\text { It shows proportion of long term } \\
\text { outside debt and shareholders } \\
\text { capital. }\end{array}$ & Debt- equity ratio $=\frac{\text { Long-term Debt }}{\text { Net worth }}$ \\
\hline & $\mathrm{D} / \mathrm{A}$ & $\begin{array}{l}\text { Debt to asset ratio demonstrate } \\
\text { how much of long-term debt is } \\
\text { backed by firm's asset. }\end{array}$ & Debt to Asset Ratio $=\frac{\text { Long term Debt }}{\text { Net Asset }}$ \\
\hline
\end{tabular}

Compiled by author

Table (3) contains statistic value of proximity test to judge the closeness of parameters value between acquirers and the targets. 
Table 3

\begin{tabular}{|c|c|c|c|c|c|c|c|c|}
\hline & \multicolumn{2}{|c|}{$\begin{array}{l}\text { Correlation } \\
\text { between Vectors of } \\
\text { Values }\end{array}$} & \multirow{4}{*}{\multicolumn{3}{|c|}{ Proximity Test }} & & \multicolumn{2}{|c|}{$\begin{array}{l}\text { Correlation between } \\
\text { Vectors of Values }\end{array}$} \\
\hline & CUR(A) & CUR(B) & & & & & $\mathrm{CR}(\mathrm{A})$ & $\mathrm{CR}(\mathrm{B})$ \\
\hline CUR(A) & 1.000 & -.046 & & & & $\mathrm{CR}(\mathrm{A})$ & 1.000 & -.027 \\
\hline \multirow[t]{3}{*}{ CUR(B) } & -.046 & 1.000 & & & & $\mathrm{CR}(\mathrm{B})$ & -.027 & 1.000 \\
\hline & \multicolumn{2}{|c|}{$\begin{array}{l}\text { Correlation } \\
\text { between Vectors of } \\
\text { Values }\end{array}$} & & \multicolumn{2}{|c|}{$\begin{array}{l}\text { Correlation between } \\
\text { Vectors of Values }\end{array}$} & & \multicolumn{2}{|c|}{$\begin{array}{l}\text { Correlation between } \\
\text { Vectors of Values }\end{array}$} \\
\hline & $\mathrm{QR}(\mathrm{A})$ & $\mathrm{QR}(\mathrm{B})$ & & GPM\%(A) & GPM\%(B) & & NPM\%(A) & NPM $\%(B)$ \\
\hline $\mathrm{QR}(\mathrm{A})$ & 1.000 & -.042 & GPM\%(A) & 1.000 & .060 & NPM\%(A) & 1.000 & .156 \\
\hline \multirow[t]{3}{*}{$\mathrm{QR}(\mathrm{B})$} & -.042 & 1.000 & GPM $\%(B)$ & .060 & 1.000 & NPM $\%(B)$ & .156 & 1.000 \\
\hline & \multicolumn{2}{|c|}{$\begin{array}{l}\text { Correlation } \\
\text { between Vectors of } \\
\text { Values }\end{array}$} & & \multicolumn{2}{|c|}{$\begin{array}{l}\text { Correlation between } \\
\text { Vectors of Values }\end{array}$} & & \multicolumn{2}{|c|}{$\begin{array}{l}\text { Correlation between } \\
\text { Vectors of Values }\end{array}$} \\
\hline & $\operatorname{EPS}(\mathrm{A})$ & EPS(B) & & $\mathrm{D} / \mathrm{E}(\mathrm{A})$ & $\mathrm{D} / \mathrm{E}(\mathrm{B})$ & & $\mathrm{D} / \mathrm{A}(\mathrm{A})$ & $\mathrm{D} / \mathrm{A}(\mathrm{B})$ \\
\hline EPS(A) & 1.000 & -.108 & $\mathrm{D} / \mathrm{E}(\mathrm{A})$ & 1.000 & -.255 & $\mathrm{D} / \mathrm{A}(\mathrm{A})$ & 1.000 & -.270 \\
\hline $\mathrm{EPS}(\mathrm{B})$ & -.108 & 1.000 & $\mathrm{D} / \mathrm{E}(\mathrm{B})$ & -.255 & 1.000 & $\mathrm{D} / \mathrm{A}(\mathrm{B})$ & -.270 & 1.000 \\
\hline
\end{tabular}

Source: SPSS Statistics 22

Proximity test was done to check whether there was a relationship between financial parameters between acquirers and the targets. The co-relation was found to be negative for parameters like CUR, QR, CR, EPS, D/E and D/A. This shows that there was difference in values of these parameters between acquirers and targets. For remaining parameters like GPM and NPM, there was a poor co-relation. Therefore, proximity test statistics demonstrate difference in parameters value but whether this difference was statistically significant or not was determined by other tools.

\subsection{Statistical tools and techniques used to check Hypothesis}

Software used for data analysis was SPSS-22. Normality of data has been tested by calculating mean, median, skewness and kurtosis using Descriptive analysis and KS-SW test. Data Analysis has been done using Mann Whitney U-Test, Two-Sample Kolmogorov-Smirnov Test, Wilcoxon Signed Ranks Test and Proximity analysis through co-relation

Table (4) contains Descriptive analysis (Mean, median, Std. Dev.) and Table (5) provides KS-SW test for normality. Table 4. Descriptive Statistics containing Mean, Median Standard Dev., Skewness and Kurtosis. 
Raghawendra Kumar and Meghna Chhabra

Table 4

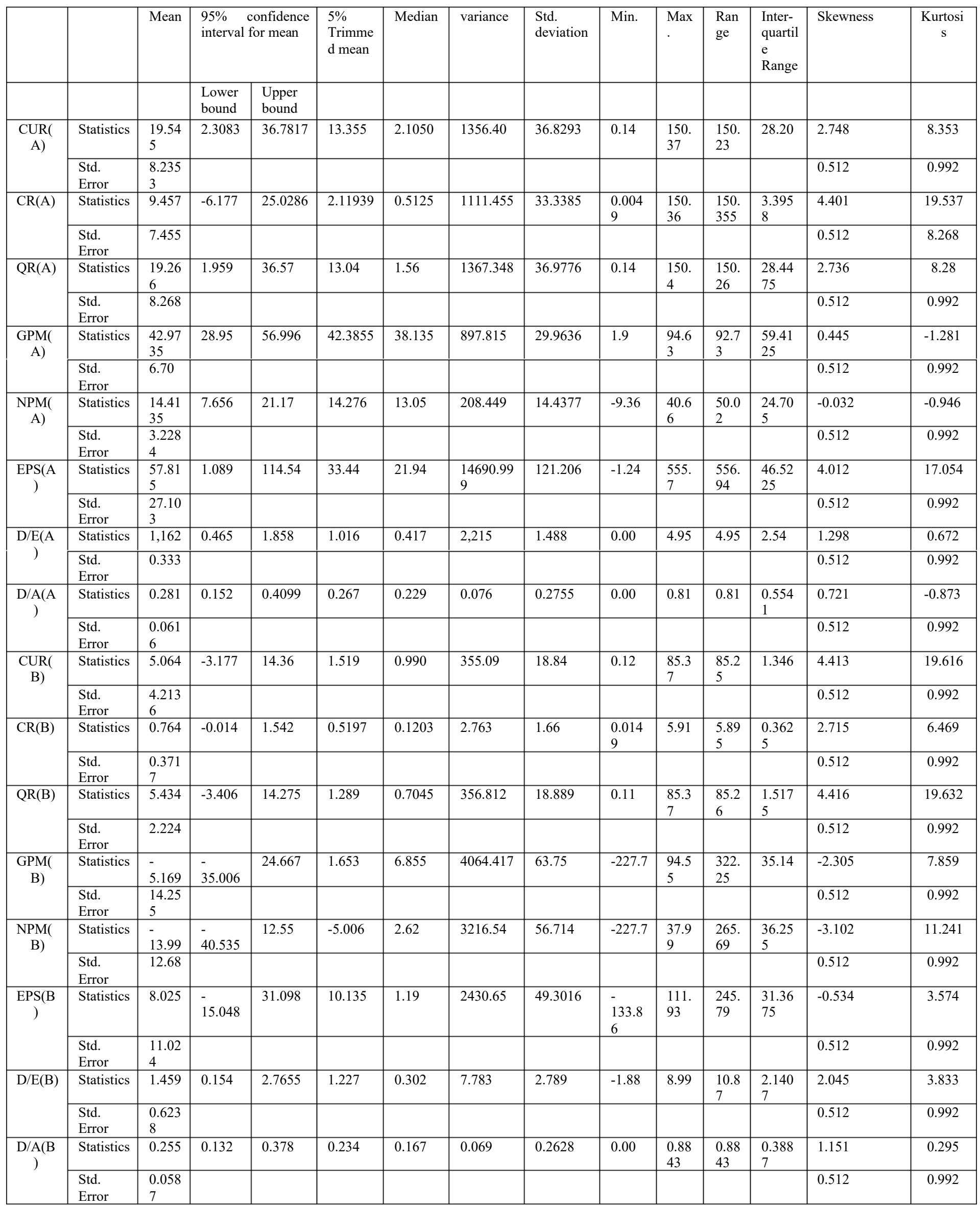


Decoding Scale and Size of The Acquired and The Acquirer: An Empirical Analysis

Table $5 \mathrm{KS}$ and SW normality Test

\begin{tabular}{|c|c|c|c|c|c|c|c|c|c|c|c|c|c|}
\hline \multicolumn{14}{|c|}{ Tests of Normality } \\
\hline & \multicolumn{3}{|c|}{ Kolmogorov-Smirnov ${ }^{a}$} & \multicolumn{3}{|c|}{ Shapiro-Wilk } & & \multicolumn{3}{|c|}{ Kolmogorov-Smirnov ${ }^{a}$} & \multicolumn{3}{|c|}{ Shapiro-Wilk } \\
\hline & Statistic & $\mathrm{df}$ & Sig. & Statistic & df & Sig. & & Statistic & df & Sig. & Statistic & df & Sig. \\
\hline $\operatorname{CUR}(A)$ & .305 & 20 & .000 & .593 & 20 & .000 & $\operatorname{CUR}(\mathrm{B})$ & .441 & 20 & .000 & .293 & 20 & .000 \\
\hline $\mathrm{CR}(\mathrm{A})$ & .442 & 20 & .000 & 299 & 20 & .000 & $\mathrm{CR}(\mathrm{B})$ & .378 & 20 & .000 & .491 & 20 & .000 \\
\hline $\mathrm{QR}(\mathrm{A})$ & .302 & 20 & .000 & .592 & 20 & .000 & $\mathrm{QR}(\mathrm{B})$ & .456 & 20 & .000 & .290 & 20 & .000 \\
\hline GPM $\%(A)$ & .202 & 20 & .032 & .899 & 20 & .039 & GPM\%(B) & .262 & 20 & .001 & .754 & 20 & .000 \\
\hline NPM $\%(A)$ & .106 & 20 & $.200^{*}$ & .966 & 20 & .670 & NPM\%(B) & .273 & 20 & .000 & .647 & 20 & .000 \\
\hline $\operatorname{EPS}(\mathrm{A})$ & .313 & 20 & .000 & .453 & 20 & .000 & EPS(B) & .216 & 20 & .016 & .859 & 20 & .008 \\
\hline$D / E(A)$ & .265 & 20 & .001 & .781 & 20 & .000 & $\mathrm{D} / \mathrm{E}(\mathrm{B})$ & .290 & 20 & .000 & .694 & 20 & .000 \\
\hline $\mathrm{D} / \mathrm{A}(\mathrm{A})$ & .188 & 20 & .061 & .862 & 20 & .009 & $\mathrm{D} / \mathrm{A}(\mathrm{B})$ & .236 & 20 & .005 & .849 & 20 & .005 \\
\hline \multicolumn{14}{|c|}{${ }^{\star}$. This is a lower bound of the true significance. } \\
\hline a. Lilliefor & gnificance & 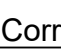 & ction & & & & & & & & & & \\
\hline
\end{tabular}

Output generated from SPSS Statistics 22

In K-S test of normality, significance value of most ratios except NPM\%(A) (0.200) and DA(A) (0.061) are greater than 0.05. Data was found to be non-normal for most of other financial ratios [CUR, CR, QR, GPM, NPM, EP, D/E, D/A], which were less than 0.05.

Since the value of mean and median of different parameters mentioned for acquirers and target are not equal and skewness and kurtosis value are not equal to zero, and since p-value of nearly all financial parameters was found to be less than 0.05 , data (financial ratio) was found to be non-normal distributed. Therefore, non-parametric tests were more suitable for analysing the data at $5 \%$ of significance level. Statistical tools used to perform analysis were MannWhitney U test, Two sample K-S test and Wilcoxon Signed Rank test to test difference of mean of median.

\section{MANN-WHITNEY U-TEST}

The Mann-Whitney $U$ test is a nonparametric procedure that determines if ranked scores (i.e., ordinal data) in two independent groups differ. It is also used to analyze interval or ratio scale variables that are not normally distributed.

Table (6) contains Mann Whitney U-test and Table (7) mentions Mann Whitney U-test statistics.

Table 6 Mann Whitney U Test

\begin{tabular}{|c|c|c|c|c|c|c|c|c|c|}
\hline \multicolumn{10}{|c|}{ Ranks } \\
\hline & Type & $\mathrm{N}$ & $\begin{array}{l}\text { Mean } \\
\text { Rank }\end{array}$ & $\begin{array}{l}\text { Sum of } \\
\text { Ranks }\end{array}$ & & Type & $\mathrm{N}$ & $\begin{array}{l}\text { Mean } \\
\text { Rank }\end{array}$ & $\begin{array}{l}\text { Sum of } \\
\text { Ranks }\end{array}$ \\
\hline \multirow[t]{3}{*}{ CUR } & Acquirer & 20 & 23.85 & 477.00 & \multirow{3}{*}{ NPM } & Acquirer & 20 & 25.05 & 501.00 \\
\hline & Target & 20 & 17.15 & 343.00 & & Target & 20 & 15.95 & 319.00 \\
\hline & Total & 40 & & & & Total & 40 & & \\
\hline \multirow[t]{3}{*}{ CR } & Acquirer & 20 & 24.03 & 480.50 & \multirow{3}{*}{ EPS } & Acquirer & 20 & 25.05 & 501.00 \\
\hline & Target & 20 & 16.98 & 339.50 & & Target & 20 & 15.95 & 319.00 \\
\hline & Total & 40 & & & & Total & 40 & & \\
\hline QR & Acquirer & 20 & 23.33 & 466.50 & $\mathrm{DE}$ & Acquirer & 20 & 20.98 & 419.50 \\
\hline
\end{tabular}


Raghawendra Kumar and Meghna Chhabra

\begin{tabular}{|c|c|c|c|c|c|c|c|c|c|}
\hline & Target & 20 & 17.68 & 353.50 & \multirow{2}{*}{\multicolumn{2}{|c|}{\begin{tabular}{|l|l|} 
Target \\
Total \\
\end{tabular}}} & \multirow{2}{*}{$\frac{20}{40}$} & \multirow[t]{2}{*}{20.03} & \multirow[t]{2}{*}{400.50} \\
\hline & Total & 40 & & & & & & & \\
\hline \multirow[t]{3}{*}{ GPM } & Acquirer & 20 & 26.70 & 534.00 & \multirow[t]{3}{*}{ DA } & Acquirer & 20 & 21.13 & 422.50 \\
\hline & Target & 20 & 14.30 & 286.00 & & Target & 20 & 19.88 & 397.50 \\
\hline & Total & 40 & & & & Total & 40 & & \\
\hline
\end{tabular}

Output generated from SPSS Statistics 22

Table 7 Mann Whitnet U Test

\begin{tabular}{|l|r|r|r|r|r|r|r|r|}
\hline \multicolumn{7}{|c|}{ Test Statistics $^{\mathrm{a}}$} \\
\hline & \multicolumn{1}{|c|}{ CUR } & \multicolumn{1}{c|}{ CR } & \multicolumn{1}{c|}{ QR } & \multicolumn{1}{c|}{ GPM } & \multicolumn{1}{c|}{ NPM } & \multicolumn{1}{c|}{ EPS } & \multicolumn{1}{c|}{ DE } & DA \\
\hline $\begin{array}{l}\text { Mann-Whitney } \\
\text { U }\end{array}$ & 133.000 & 129.500 & 143.500 & 76.000 & 109.000 & 109.000 & 190.500 & 187.500 \\
\hline Wilcoxon W & 343.000 & 339.500 & 353.500 & 286.000 & 319.000 & 319.000 & 400.500 & 397.500 \\
\hline Z & -1.813 & -1.907 & -1.529 & -3.355 & -2.462 & -2.462 & -.257 & -.339 \\
\hline $\begin{array}{l}\text { Asymp. Sig. (2- } \\
\text { tailed) }\end{array}$ & .070 & .056 & .126 & .001 & .014 & .014 & .797 & .735 \\
\hline $\begin{array}{l}\text { Exact Sig. } \\
\text { [2*(1-tailed } \\
\text { Sig.)] }\end{array}$ & $.072^{\mathrm{b}}$ & $.056^{\mathrm{b}}$ & $.127^{\mathrm{b}}$ & $.001^{\mathrm{b}}$ & $.013^{\mathrm{b}}$ & $.013^{\mathrm{b}}$ & $.799^{\mathrm{b}}$ & $.738^{\mathrm{b}}$ \\
$\begin{array}{l}\text { a. Grouping Variable: Type } \\
\text { b. Not corrected for ties. }\end{array}$ & & & & & & \\
\hline
\end{tabular}

Output generated from SPSS Statistics 22

SPSS output finds generated values of Asymp Sig, (2-tailed) for GPM (0.001), NPM (0.014) and EPS (0.014) as significant as these values are less than 0.05. Therefore Null Hypothesis is rejected. So we can say that Acquirers and Targets were having significant different values for parameters namely GPM, NPM and EPS. For CUR (0.07), CR (0.056), CR (O.126), DE (0.797) and DA ( 0.735) ratios, Asymp Sig, (2-tailed) values are much higher than 0.05. It means, statistics failed to reject Null Hypothesis. Therefore, no significant difference was found in Liquidity position of Acquirers and the Targets and also no significant difference was found in Capital Structure of Acquirers and Targets.

\section{TWO-SAMPLE KOLMOGOROV-SMIRNOV TEST}

Table 8

\begin{tabular}{|c|c|c|c|c|c|c|c|c|c|}
\hline \multicolumn{10}{|c|}{ Test Statistics ${ }^{\mathbf{a}}$} \\
\hline & & CUR & $\mathrm{CR}$ & QR & GPM & NPM & EPS & DE & DA \\
\hline \multirow[t]{3}{*}{ Most Extreme Differences } & Absolute & .350 & .350 & .300 & .550 & .350 & .500 & .150 & .200 \\
\hline & Positive & .050 & .100 & .050 & .000 & .000 & .000 & .100 & .150 \\
\hline & Negative & -.350 & -.350 & -.300 & -.550 & -.350 & -.500 & -.150 & -.200 \\
\hline \multicolumn{2}{|l|}{ Kolmogorov-Smirnov Z } & 1.107 & 1.107 & .949 & 1.739 & 1.107 & 1.581 & .474 & .632 \\
\hline \multicolumn{2}{|l|}{ Asymp. Sig. (2-tailed) } & .172 & .172 & .329 & .005 & .172 & .013 & .978 & .819 \\
\hline \multicolumn{3}{|l|}{ a. Grouping Variable: Type } & & & & & & & \\
\hline
\end{tabular}

Output generated from SPSS Statistics 22 


\subsection{Testing of hypothesis}

Asymp. Sig. (2-tailed) values of GPM (0.005) and EPS (0.013) were only found to be significant since these values are less than 0.05 . So, Null Hypothesis gets rejected. Therefore, there was a significant difference in Profitability Position of Acquirers and Targets except NPM (0.117>0.05). Other ratios such as CUR (0.172), CR (0.172), QR (0.329), NPM (0.172, DE (0.978) and DA (0.819) are much greater than 0.05. therefore, test statistics failed to reject Null Hypothesis. So, no significant difference was found in Liquidity position and Capital Structure position of Acquirers and Target firms.

\section{WILCOXON SIGNED RANKS TEST}

Table 9 Wilcoxon Signed Ranks Test

\begin{tabular}{|c|c|c|c|c|c|c|c|c|c|}
\hline \multicolumn{10}{|c|}{ Ranks } \\
\hline & & $\mathrm{N}$ & $\begin{array}{r}\text { Mean } \\
\text { Rank }\end{array}$ & $\begin{array}{l}\text { Sum of } \\
\text { Ranks }\end{array}$ & & & $N$ & $\begin{array}{l}\text { Mean } \\
\text { Rank }\end{array}$ & $\begin{array}{l}\text { Sum of } \\
\text { Rank }\end{array}$ \\
\hline \multirow{4}{*}{$\begin{array}{l}\operatorname{CUR}(B)- \\
\operatorname{CUR}(A)\end{array}$} & Negative Ranks & $14^{\mathrm{a}}$ & 11.36 & 159.00 & \multirow{4}{*}{$\begin{array}{l}\text { NPM\%(B) - } \\
\text { NPM\%(A) }\end{array}$} & Negative Ranks & $16^{m}$ & 11.38 & 182.00 \\
\hline & Positive Ranks & $6^{b}$ & 8.50 & 51.00 & & \multirow{2}{*}{\begin{tabular}{|l} 
Positive Ranks \\
Ties
\end{tabular}} & $4^{n}$ & 7.00 & 28.00 \\
\hline & Ties & $b^{c}$ & & & & & $0^{\circ}$ & & \\
\hline & Total & 20 & & & & Total & 20 & & \\
\hline \multirow{4}{*}{$\begin{array}{l}\mathrm{CR}(\mathrm{B})- \\
\mathrm{CR}(\mathrm{A})\end{array}$} & Negative Ranks & $14^{d}$ & 11.00 & 154.00 & \multirow{4}{*}{$\begin{array}{l}\operatorname{EPS}(\mathrm{B}) \text { - } \\
\operatorname{EPS}(\mathrm{A})\end{array}$} & Negative Ranks & $15^{\circ}$ & 10.27 & 154.00 \\
\hline & Positive Ranks & $6^{e}$ & 9.33 & 56.00 & & Positive Ranks & $5^{q}$ & 11.20 & 56.00 \\
\hline & Ties & $0^{f}$ & & & & Ties & $0^{r}$ & & \\
\hline & Total & 20 & & & & Total & 20 & & \\
\hline \multirow{4}{*}{$\begin{array}{l}\mathrm{QR}(\mathrm{B}) \text { - } \\
\mathrm{QR}(\mathrm{A})\end{array}$} & Negative Ranks & $14^{9}$ & 11.11 & 155.50 & \multirow{4}{*}{$\begin{array}{l}D / E(B)- \\
D / E(A)\end{array}$} & Negative Ranks & $7^{s}$ & 13.86 & 97.00 \\
\hline & Positive Ranks & $6^{\mathrm{h}}$ & 9.08 & 54.50 & & Positive Ranks & $13^{t}$ & 8.69 & 113.00 \\
\hline & Ties & $b^{i}$ & & & & Ties & $\mathrm{O}^{\mathrm{u}}$ & & \\
\hline & Total & 20 & & & & Total & 20 & & \\
\hline \multirow{4}{*}{$\begin{array}{l}\text { GPM\%(B) - } \\
\text { GPM\%(A) }\end{array}$} & Negative Ranks & $17^{j}$ & 10.88 & 185.00 & \multirow{4}{*}{$\begin{array}{l}D / A(B)- \\
D / A(A)\end{array}$} & Negative Ranks & $9^{v}$ & 11.89 & 107.00 \\
\hline & Positive Ranks & $3^{k}$ & 8.33 & 25.00 & & Positive Ranks & $11^{w}$ & 9.36 & 103.00 \\
\hline & Ties & $0^{1}$ & & & & Ties & $0^{x}$ & & \\
\hline & Total & 20 & & & & Total & 20 & & \\
\hline
\end{tabular}

Output generated from SPSS Statistics 22

Table (9) contains Wilcoxon Signed Ranks Test and Table (10) contains test statistics.

Table 10

\begin{tabular}{|l|r|r|r|r|r|r|r|r|}
\hline \multicolumn{10}{|c|}{ Test Statistics $^{\mathrm{a}}$} \\
\hline & $\begin{array}{c}\text { CUR(B) - } \\
\text { CUR(A) }\end{array}$ & $\begin{array}{c}\text { CR(B) - } \\
\text { CR(A) }\end{array}$ & $\begin{array}{l}\text { QR(B) - } \\
\text { QR(A) }\end{array}$ & $\begin{array}{l}\text { GPM\%(B) - } \\
\text { GPM\%(A) }\end{array}$ & $\begin{array}{l}\text { NPM\%(B) - } \\
\text { NPM\%(A) }\end{array}$ & $\begin{array}{l}\text { EPS(B) - } \\
\text { EPS(A) }\end{array}$ & $\begin{array}{c}\text { D/E(B) - } \\
\text { D/E(A) }\end{array}$ & $\begin{array}{c}\text { D/A(B) - } \\
\text { D/A(A) }\end{array}$ \\
\hline$Z$ & $-2.016^{\mathrm{b}}$ & $-1.829^{\mathrm{b}}$ & $-1.885^{\mathrm{b}}$ & $-2.987^{\mathrm{b}}$ & $-2.875^{\mathrm{b}}$ & $-1.829^{\mathrm{b}}$ & $-.299^{\mathrm{c}}$ & $-.075^{\mathrm{b}}$ \\
\hline Asymp. Sig. (2-tailed) & .044 & .067 & .059 & .003 & .004 & .067 & .765 & .940 \\
\hline
\end{tabular}

Output generated from SPSS Statistics 22 


\subsection{Testing of hypothesis}

The above SPSS output shows that the test is significant for CUR (0.04), GPM (0.003) and NPM (0.004) using the z-approximation since the significance level $<=.05$ (the assumed à priori significance level). The p-value (Asymp. Sig. 2-tailed) is $p<0.05$ in this. Other ratios like CR (0.067), QR (0.059), EPS (0.067), DE (0.765) and DA (0.940) have values higher than 0.05 . Therefore, the Null Hypothesis for Profitability Ratios is rejected except (EPS, 0.067> 0.05), which shows that there was a significant difference in profitability between Acquirers and Targets. And for Liquidity position except CUR $(0.04<0.05)$ and Capital Structure position, statistics failed to reject the Null Hypothesis indicating that there was no significant difference between Acquirers and Targets on these two parameters.

\subsection{Analysing the Results}

Output generated from SPSS reveal that Two Sample KS test significance value for GPM $(0.005)$ and EPS (0.013) are statistically significant thus, rejects. the Null Hypothesis. Mann Whitney U-test for GPM (0.001), NPM (0.013) and EPS (0.013) are significant and rejects Null Hypothesis. Whereas, Wilcoxon Signed Rank test for GPM (0.003), NPM (0.004) and CUR $(0.044)$ are found to be significant, thus rejects the Null Hypothesis. For other ratios, all the three tests failed to reject the Null Hypothesis. Table (11) mentions the findings of Hypothesis testing using Two Sample KS test, Mann Whitney U-test and Wilcoxon Signed Ranks test.

\section{CONCLUSIONS}

Analysis of above mentioned statistical tools provide evidence to conclude that in profitability position acquirers were better in comparison to the target firms. There was a statistically significant difference between acquirers and the targets. But all the three tests failed to conclude that Liquidity position and Capital Structure position of acquirers were not significantly different from targets. Therefore, this study failed to predict any characteristic difference between acquirers and the targets particularly on parameters like liquidity and capital structure position.

\section{LIMITATIONS OF STUDY}

Lack of publicly available financial data and lack of mergers and acquisitions data and related statistics in India are the major limitations for research work. Lack of relevant literature for Indian mergers particularly by Indian researchers is another important limitation. Use of small sample size for analysing the data little bit undermined the generalization of outcomes.

Table 11 Findings of financial performance

\begin{tabular}{|l|l|l|l|l|l|l|l|}
\hline $\begin{array}{l}\text { Para- } \\
\text { meters }\end{array}$ & $\begin{array}{l}\text { Hypothesis (H0) Null } \\
\text { Hypothesis }\end{array}$ & \multicolumn{2}{l|}{ Two Sample KS test } & \multicolumn{2}{l|}{ Mann-Whitney U test } & \multicolumn{2}{l|}{ Wilcoxon Signed Ranks test } \\
\hline & \multicolumn{2}{|l|}{ Value } & Result & Value & Result & Value & Result \\
\hline CUR & $\begin{array}{l}\text { No difference in CUR } \\
\text { between Acquirers and } \\
\text { Targets }\end{array}$ & $\begin{array}{l}\text { Failed to Reject } \\
\text { Null Hypothesis }\end{array}$ & $\begin{array}{l}.072 \\
\text { Null Hypothesis }\end{array}$ & $\begin{array}{l}\text { Nailed to Reject } \\
\text { Rejected }\end{array}$ \\
\hline CR & $\begin{array}{l}\text { No difference in CR } \\
\text { between Acquirers and } \\
\text { Targets }\end{array}$ & $\begin{array}{l}\text { Failed to Reject } \\
\text { Null Hypothesis }\end{array}$ & .056 & $\begin{array}{l}\text { Failed to Reject } \\
\text { Null Hypothesis }\end{array}$ & .067 & $\begin{array}{l}\text { Failed to Reject } \\
\text { Null Hypothesis }\end{array}$ \\
\hline QR & $\begin{array}{l}\text { No difference in QR } \\
\text { between Acquirers and } \\
\text { Targets }\end{array}$ & $\begin{array}{l}\text { Failed to Reject } \\
\text { Null Hypothesis }\end{array}$ & .127 & $\begin{array}{l}\text { Failed to Reject } \\
\text { Null Hypothesis }\end{array}$ & .059 & $\begin{array}{l}\text { Failed to Reject } \\
\text { Null Hypothesis }\end{array}$ \\
\hline
\end{tabular}


Decoding Scale and Size of The Acquired and The Acquirer: An Empirical Analysis

\begin{tabular}{|l|l|l|l|l|l|l|l|}
\hline GPM & $\begin{array}{l}\text { No difference in GPM } \\
\text { between Acquirers and } \\
\text { Targets }\end{array}$ & $\begin{array}{l}\text { Null Hypothesis } \\
\text { Rejected }\end{array}$ & $\begin{array}{l}\text { Null Hypothesis } \\
\text { Rejected }\end{array}$ & .003 & $\begin{array}{l}\text { Null Hypothesis } \\
\text { Rejected }\end{array}$ \\
\hline NPM & $\begin{array}{l}\text { No difference in NPM } \\
\text { between Acquirers and } \\
\text { Targets }\end{array}$ & $\begin{array}{l}\text { Failed to Reject } \\
\text { Null Hypothesis }\end{array}$ & .013 & $\begin{array}{l}\text { Null Hypothesis } \\
\text { Rejected }\end{array}$ & .004 & $\begin{array}{l}\text { Null Hypothesis } \\
\text { Rejected }\end{array}$ \\
\hline EPS & $\begin{array}{l}\text { No difference in EPS } \\
\text { between Acquirers and } \\
\text { Targets }\end{array}$ & $\begin{array}{l}\text { Null Hypothesis } \\
\text { Rejected }\end{array}$ & .013 & $\begin{array}{l}\text { Null Hypothesis } \\
\text { Rejected }\end{array}$ & .067 & $\begin{array}{l}\text { Failed to Reject } \\
\text { Null Hypothesis }\end{array}$ \\
\hline DE & $\begin{array}{l}\text { No difference in DE } \\
\text { between Acquirers and } \\
\text { Targets }\end{array}$ & $\begin{array}{l}\text { Failed to Reject } \\
\text { Null Hypothesis }\end{array}$ & .799 & $\begin{array}{l}\text { Failed to Reject } \\
\text { Null Hypothesis }\end{array}$ & .765 & $\begin{array}{l}\text { Failed to Reject } \\
\text { Null Hypothesis }\end{array}$ \\
\hline DA & $\begin{array}{l}\text { No difference in DA } \\
\text { between Acquirers and } \\
\text { Targets }\end{array}$ & $\begin{array}{l}\text { Failed to Reject } \\
\text { Null Hypothesis }\end{array}$ & .738 & $\begin{array}{l}\text { Failed to Reject } \\
\text { Null Hypothesis }\end{array}$ & .940 & $\begin{array}{l}\text { Failed to Reject } \\
\text { Null Hypothesis }\end{array}$ \\
\hline
\end{tabular}

\section{SCOPE OF FURTHER RESEARCH}

This research paper will further enrich the availability of large chunk of existing literature in the field of $\mathrm{M} \& \mathrm{~A}$ research. For future research scholars, it will act as a guide to enhance their research outcomes.

\section{REFERENCES}

[1] Accenture. 2006. How cross-border acquisitions are powering growth. Accenture.

[2] Accenture, and CII. 2008. High performance through mergers and acquisitions: India's new dynamics. Accenture and CII.

[3] Agarwal, M. (2002). Analyses of Mergers in India. M.Phil. Dissertation. University of Delhi. 2.

[4] Agarwal, M (2003). Analyses of Mergers in India. Unpublished M. Phil Dissertation submitted to the University of Delhi. Delhi School of Economics.

[5] Agarwal M., \& Sensarma, R. (2007). Determinants of Merger Activity: Evidence From India. International Journal of Financial Services Management, Vol. 2, No. 4, pp. 277-288.

[6] Altman, E.I. (1968). Financial Ratios, Discriminant Analysis and the Prediction of Corporate Bankruptcy. Journal of Finance, 23(4), 589-608.

[7] Amano, Y. (2009). Democratization and Power-Sharing for Alternative Social Orders: Lessons from Economic Liberalization and Water Conflict in India. A thesis submitted in partial fulfilment of the requirements for the degree of Master of Arts, to the Institute of Political Economy, Carleton University. ProQuest dissertations and theses.

[8] Andrade., G, Mitchell, M., \& Stafford, E. (2001). New Evidence and Perspectives on mergers. Journal of Economic Perspectives, Vol. 15, No. 2, pp. 103-120.

[9] Ansoff, H.I., \& Weston, J.F. (1962). Merger Objectives and Organisational Structure. The Quarterly Review of Economics and Business, Vol. 2, pp. 49-58.

[10] Athukrola, P.C. (2009). Outward foreign direct investment from India. Asian Development Review, Vol. 26, No. 2, pp. 125-153. 
[11] Barnes, p. (1990). The Prediction of Takeover Targets in the UK by Means of Multiple Discriminant Analysis. Journal of Business Finance \& Accounting, 17(1), 73-84.

[12] Basant, R. (2000). Corporate Response to Economic Reforms. Economic and Political Weekly, Vol. 35, No. 10, pp. 813-822.

[13] Basant, R., \& Morris, S. (2000). Competition Policy in India: Issues for a Globalising Economy. Economic \& Political Weekly, Vol. 35, No. 31, pp. 2735-2747.

[14] Beaver, W.H. (1966). Financial Ratios as Predictors of Failures. Journal of Accounting Research, Supplement, 4(3), 71-111.

[15] Beena, P L (2000). An Analysis of Mergers in the Private Corporate Sector in India. Working Paper No 301, Centre for Development Studies, Thiruvananthapuram.

[16] - (2001). An Analysis of Mergers in the Private Corporate Sector in India. Working Paper No. 301, Centre for Development Studies (CDS), Trivandrum.

[17] - (2001a). Intangibles and Finance: Motives and Consequences of Mergers in the Indian Corporate Sector in P Banergee and F J Richter (eds), Intangibles in Competition and Cooperation. Euro-Asian Perspectives, Palgrave, New York, pp. 53-73.

[18] - (2001b). An Overview of the Mergers and Acquisitions during the Post-Liberalisation Era. Business Digest, Vol XVI, Issue 16, August 16-31, FICCI

[19] - (2004). Towards Understanding the Merger Wave in the Indian Corporate Sector: A Comparative Perspective. Working Paper No. 355, pp. 1-44, CDS, Trivandrum.

[20] Berger, A.N., \& Humphrey, D.B. (1992). Megamergers in Banking and Use of Cost Efficiency as an Antitrust Defense. Antitrust Bulletin, Vol. 37.

[21] Berkovitch, E., \& Narayana, M.P. (1993). Motives for Takeovers: An Empirical Investigation. Journal of Financial and Quantitative Analysis, 28 (3), 347-362.

[22] Berle, Adolf and Gardiner Means (1932). The Modern Corporation and Private Property. New York: MacMillan.

[23] Bhalla, P (2011). Determinants of Mergers and Acquisitions of Firms in the Indian Financial Sector: An Empirical Analysis. The IUP Journal of Business Strategy, Vol. VIII, No. 3, pp. 118.

[24] Bhattacharjea, A. (2000). Prédation, Protection and the Public Interest. Economic \& PoliticalWeekly, .Vol. 35, Issue No. 49, pp. 4327-4336.

[25] - (2001). Competition Policy: India and the WTO. Economic \& Political Weekly, December 22, PP. 4710-13.

[26] - (2003). Trade, Investment, Competition Policy: An Indian Perspective in Aditya Mattoo and Robert M Stern (eds). India and the WTO (A Co-publication of the World Bank and Oxford University Press).

[27] Bolton, P., \& Schartstein, D.S. (1998). Corporate Finance, the Theory of the Firm and Organisations. Journal of Economic Perspectives, Vol 12, No 4, pp. 95-114.

[28] Bruner, R. (2004). Where M\&A Pays and Where it Strays: A Survey of the Research. Journal of Applied Corporate Finance, 16(4), 63-76. 
[29] Bryson, J. (2003). Managing HRM risk in a merger. Employee Relations, Vol. 25 No. 1, pp. 1430.

[30] Buckley, P.J., \& Casson, M.C. (1976). The Future of Multinational Enterprise. Macmillan, London. DOl 10.1007/978-1-349-21204-0.

[31] Cabanda, E., \& Pascual, M.P. (2007). Mergers in the Philippines: Evidence in the Corporate Performance of William, Gothong and Aboitiz (WG\&A) Shipping Companies. Journal of Business Case Studies, Vol. 3, No. 4, pp. 87-100.

[32] Cantwell, J., \& Santangelo, G.D. (2002). M\&As and the Global Strategies of TNCs. The Developing Economies, 40(4), 400 - 434.

[33] Caves, R.E. (1991). 'Corporate Mergers in International Economic Integration' in A Giovanni and C Mayer (eds). European Financial Integration, Cambridge University Press, Cambridge, pp. 136-60.

[34] Chandrasekhar, C P (2003): The End to Indian Anti- Trust', Frontline, Volume 20, No 1, pp. 19.

[35] Coase, R.H. (1937). The Nature of the Firm. Economica, 4(16), pp. 386-405.

[36] Cummins, J.D., Tennyson, S.L. \& Weiss, M.A. (1999). Efficiency, Scale Economies and Consolidation. Journal of Banking and Finance, Vol. 23, Nos. 2-4, pp. 325-357.

[37] Deora, M.M. (2011). Industry-friendly cci will not tolerate mergers that create monopolies or abuse of dominance. New Delhi: Federation of Indian Chambers of Commerce and Industry

[38] Dietrich, J Kimball and Sorensen, E (1984). An Application of Logit Analysis to Prediction of Merger of Targets, Journal of Business Research, 12(3), 393-402.

[39] Dunning, J.H. (1977). Trade, location of economic activity and the MNE: a search for an eclectic approach, in Ohlin, B., Hesselborn, P.O. and Wijkman, P.M. (Eds). The International Allocation of Economic Activity, Macmillan, London, pp. 395-418.

[40] Dunning, J.H. (1988). The eclectic paradigm of international production: a restatement and some possible extensions. Journal of International Business Studies, Vol. 19, No. 1, pp. 1-31.

[41] Dunning, J.H. (1993). Multinational Enterprises and the Global Economy. Retrieved from https://mpra.ub.uni-muenchen.de/id/eprint/18660

[42] Dunning, J.H., Kim, C., \& Park, D. (2008). Old wine in new bottles: a comparison of emerging market TNCs today and developed-country TNCs thirty years ago, in Sauvant, K. (Ed.), The Rise of Transnational Corporations from Emerging Markets: Threat or Opportunity?. Edward Elgar, Northampton, MA, pp. 158-180.

[43] Dyer, J.H., Kale, P., \& Singh, H. (2004). When to Ally and When to Acquire. Harvard Business Review, 82(7/8), 109-115.

[44] Evenett, S.J. (2002). Merger and Anti Cartel Policies in an Era of Integrating Markets in B Hoekman, A Mattoo and P English (eds). Development, Trade and the WTO, World Bank, Washington DC.

[45] Paul M.HealyKrishna G.PalepuRichard S.Ruback (1992). Does corporate performance improve after mergers? Journal of Financial Economics, Volume 31, Issue 2, pp. 135-175. 
[46] Farole, T., \& Winkler, D. (2014). Making Foreign Direct Investment Work for Sub-Saharan Africa: Local Spillovers and Competitiveness in Global Value Chains. Directions in Development, World Bank, Washington, DC, doi: 10.1596/978-1-4648-0126-6.

[47] Gopinath, S. (2007). Overseas Investments by Indian Companies - Evolution of Policy and Trends. RBI Bulletin, February, Vol LXI, No 2.

[48] Gort, M. (1969). An Economic Disturbance Theory of Mergers'. Quarterly Journal of Economics, Vol 83, pp. 624-42.

[49] Grossman, S., \& Oliver H. (1986). The Costs and Benefits of Ownership: A Theory of Vertical and Lateral Integration'. Journal of Political Economy, 94, pp. 691-719.

[50] Gubbi, S.R., Aulakh, P.S., Ray, S., Sarkar, M.B., \& Chittoor, R. (2010). "Do international acquisitions by emerging economy firms create shareholder value? The case of Indian firms." Journal of International Business Studies, Vol. 41, No. 3, pp. 397-418.

[51] Harris, R.S., Stewart, J.F., Guilkey, D.K., \& Carleton, W.T. (1982). "Characteristics of Acquired Firms: Fixed and Random Coefficients Probit Analyses". Southern Economic Journal, 49(1), 164-184.

[52] Hart, O., \& John M. (1990). 'Property Rights and the Nature of the Firm. Journal of Political Economy, 98, pp. 1119-1158.

[53] Hay, D.A., \& Guy S.L. (1998). 'When Do Firms Go in for Growth by Acquisitions?' Oxford Bulletin of Economics and Statistics, Vol 60, No. 2, PP. 143-164.

[54] Horn, H., \& Persson, L. (2001). The Equilibrium Ownership of an International Oligopoly.' Journal of International Economics, 53, pp. 307-333.

[55] Jensen, M. (1988). Takeovers: Their Causes and Consequences. Journal of Economic Perspectives, Vol. 2, pp. 21-48.

[56] Jensen, M.C., \& Ruback, R.S. (1983). "The Market for Corporate Control, The Scientific Evidence." Journal of Financial Economics, 11(1-4), 5-50.

[57] Jhunjhunwala, D.A. (2010). CII News Update. Confederation of Indian Industry.

[58] Johanson, J., \& Vahlne, J.E. (1977). "Internationalization process of firm - model of knowledge development and increasing foreign market commitments". Journal of Business Studies, Vol. 8 No. 1, pp. 23-32.

[59] Koi-Akrofii, G.Y. (2014). "Motives for telecom mergers and acquisitions". International Journal of Innovation and Applied Sciences, Vol. 9, No. 4, pp. 1809-1817.

[60] Kumar, B.R., \& Rajib, P. (2007). "Characteristics of merging firms in India: an empirical examination”. Vikalpa, Vol. 32, No. 1, pp. 27-44.

[61] Kumar, N. (2000). 'Mergers and Acquisitions by MNEs: Patterns and Implications.' Economic \& Political Weekly, Vol 35, No 32, pp. 2851-2858.

[62] Lall, S. (2002). 'Implications of Cross-Border Mergers and Acquisitions by TNCs in Developing Countries: A Beginners' Guide'. Working Paper No 88, Department of International Development, QEH, Oxford. 
[63] Laura, G.-M., Kenyon, T., Margalit, Y., Reis, J.G., \&Varela, G. (2015). New Voices in Investment: A Survey of Investors from Emerging Countries. World Bank: World Bank Studies, Washington, DC.

[64] Lommerud, K.E., Straume O.R., \& Sorgard, L. (2005). 'Downstream Merger with Upstream Market Power'. European Economic Review, 49, pp. 717-743.

[65] Luo, Y., \& Tung, R.L. (2007). "International expansion of emerging market enterprises: a spring board perspective.” Journal of International Business Studies, Vol.38, No.4, pp. 481-498.

[66] Mani, R. (2009). Overcoming IT Challenges in Mergers and Acquisitions. Cognizant. Retrieved from https://infotech.report/Resources/Whitepapers/782bfdf7-5e33-4bad-af60ff60f4486f14_5110f1d1-claa-4be9-9e52-769f1ddbe303_OvercomingITChallenges.pdf

[67] Manne, H.G. (1965). "Mergers and the Market for Corporate Control." Journal of Political Economy, 73(2), 110-119.

[68] Mantravadi, P., \& Reddy, A. (2008). "Post-merger performance of acquiring companies from different industries in India." International Research Journal of Finance and Economics, Vol. 22, pp. 192-204.

[69] March, J.G. (1991). "Exploration \& exploitation in organizational learning." Organization Science, Vol. 2, No. 1, pp. 71-87.

[70] Martynova, M., Oosting, S., \& Renneboog, L. (2006). The long term operating performance of European mergers and acquisition. working paper (137). Retrieved from https://ecgi.global/sites/default/files/working_papers/documents/SSRN-id944407.pdf

[71] McDougall, F.M., \& Round, D.K. (1984).“A comparison of diversifying and non-diversifying Australian industrial firms”. Academy of Management Journal, Vol. 27, No. 2, pp. 384-398.

[72] Meador, A.L., Church, P.H., \& Rayburn, G.L. (1996). "Development of Prediction Models for Horizontal and Vertical Mergers". Journal of Financial and Strategic Decisions, 9(1), 11-23.

[73] Melicher, R. et al. (1983). 'A Time Series Analysis of Aggregate Merger Activity'. The Review of Economics \& Statistics, Vol. 65, pp. 423-430.

[74] Mitchell, M.L., \& Mulherin, J.H. (1996). The Impact of Industry Shocks on Takeover and Restructuring Activity'. Journal of Financial Economics, 41, pp. 193-229.

[75] Moeller, S.B., \& Schlingemann, F.P. (2005). "Global diversification and bidder gains: a comparison between cross-border and domestic acquisitions". Journal of Banking \& Finance, Vol. 29, No. 3, pp. 533-564.

[76] Monroe, Robert.J., \& Simowitz, Michael.A. (1971). Investment Characteristics of Conglomerate Targets: A Discriminant Analysis. Southern Journal of Business, 15, 1-16.

[77] Myers, S.C., \& Majluf, N.S. (1984). "Corporate Financing and Investment Decisions When Firms Have Information that Investors Do Not Have". Journal of Financial Economics, 13(2), $187-221$.

[78] Nagaraj, R. (2006). 'Indian Investments Abroad: What Explains the Boom?. Economic \& Political Weekly, Vol 41, No 46, pp. 4716-4718. 
[79] Nayyar, D. (2007). The Internationalisation of Firms from India: Investments, Mergers and Acquisitions. SLPTMD WP No 004, Department of International Development, QEH, London: University of Oxford.

[80] Neary, J.P. (2007). 'Cross-border Mergers as Instruments of Comparative Advantage'. The Review of Economic Studies, Volume 74, Issue 4, pp. 1229-1257.

[81] Nguyen, S.A., \& Ollinger, M. (2006). "Mergers and Acquisitions and Productivity in the US Meat Products Industries: Evidence from the Micro Data". American Journal of Agricultural Economics, Vol. 88, No. 3, pp. 606-616.

[82] Nguyen, H.T., Yung, K., \& Sun, Q. (2012). "Motives for mergers and acquisitions :ex-postmarket evidence from the US". Journal of Business Finance \& Accounting, Vol. 39, Nos 9-10, pp. 1357-1375.

[83] Nunnenkamp, P., Andres, M.S., Vadlamannati, K.C., \& Waldkirch, A. (2012). "What drives India's outward FDI?". South Asian Journal of Macroeconomics and Public Finance, Vol. 1, No. 2, pp. 245-279.

[84] Owen, S. (1995). The Characteristics of Firms Involved in UK Acquisitions (Working Paper). Department of Economics and Finance, Brunel University, Uxbridge, Middlesex, UK.

[85] Peel, M.J. (1995). "The Impact of Corporate Restructuring: Mergers, Divestments and MBOs". Long Range Planning, 28(2), 92-101.

[86] Peristiani, S. (1997). "Do Mergers Improve the X-Efficiency and Scale Efficiency of US Banks? Evidence from the 1980s". Journal of Money, Credit and Banking, Vol. 29, No. 3, pp. 326-337.

[87] Pillania, R.K. (2008), "Creation and categorization of knowledge in automotive components SMEs in India", Management Decision, Vol. 46, No. 10, pp. 1452-1464.

[88] Pilloff, S.J., \& Santomero, A.M. (1997). "The Value Effects of Bank Mergers and Acquisitions". The Wharton Financial Institutions Centre, Vol. 97, No. 7, pp. 1-30.

[89] Post, A. (1994). Anatomy of a Merger: The Causes and Effects of Mergers and Acquisitions. Englewood Cliffs, New Jersey: Prentice-Hall,

[90] Pradhan, J.P., \& Abraham, V. (2005). Overseas Mergers and Acquisitions by Indian Enterprises. Indian Journal of Economics, Vol. 85, No. 33, 365-386.

[91] Qiu, L.D., \& W Zhou (2006). 'International Mergers: Incentives and Welfare'. Journal of International Economics, 68, pp. 38-58.

[92] Ramaswamy, K.V. (2006). 'Competition Policy and Practice in Canada: Salient Features and Some Perspectives for India'. Economic and Political Weekly, Vol. 41, No. 19, pp. 1903-1911.

[93] Rani, N., Yadav, S.S. \& Jain, P.K. (2010). "Corporate merger practices in India: an empirical study", Proceedings of Tenth Global Conference on Flexible Systems Management GLOGIFT10, Graduate School of System Design and Management Collaboration Complex, Hiyoshi Campus, Keio University Japan. Retrieved from: SSRN: https://ssrn.com/abstract=2043698

[94] Reddy, K.S. (2014). "Extant reviews on entry-mode/internationalization, mergers \& acquisitions, and diversification: understanding theories and establishing interdisciplinary research". Pacific Science Review, Vol. 16, No. 4, pp. 250-274. 
[95] Reddy, K.S. (2015a). "Determinants of cross-border mergers and acquisitions: a comprehensive review and future direction". Retrieved from :http://mpra.ub.uni-muenchen.de/63969/ (accessed 28 May 2015).

[96] Reddy, K.S. (2015b)."Macroeconomic change and cross-border mergers and acquisitions: the Indian experience, 1991-2010". Journal of Comparative International Management, Vol. 18, No. 2, pp. 1-24

[97] Rhaode, S.A. (1998). "The Efficiency Effects of Bank Mergers: An Overview of Case Studies of Nine Mergers". Journal of Banking and Finance, Vol. 22, No. 3, pp. 273-291.

[98] Saha, Biswatosh. (2001). 'Investment Policy in India'. paper presented in a seminar organised by CUTS Centre for International Trade, Economics and Environment, Jaipur.

[99] Sanfilippo, A.S., Garcia, O.M \& Torre, O.B (2008). "Determinants of Mergers and Acquisitions in the European Financial Entities: An Analysis of Operations in the Nineties", available at http://ssrn.com/abstract=493102.

[100] Schmalensee, R. (1987). 'Horizontal Merger Policy: Problems and Changes'. Journal of Economic Perspectives, Vol 7, No 2, pp. 41-54.

[101] Selden, Larry., \& Colvin, Geoffrey. (2003). "M \& A Needn't be a Loser's Game”. Harvard Business Review, 81(6), 70-79.

[102] Seth, A., Song, K. \& Pettit, R. (2000). "Synergy, managerialism or hubris? An empiricalexamination of motives for foreign acquisitions of U.S. firms". Journal of International Business Studies, Vol. 31, No. 3, pp. 387-405.

[103] Severiens, Jacobus.T. (1991). "Creating Value through Mergers and Acquisitions: Some Motivations". Managerial Finance, 17(1), 3-7.

[104] Singh, A. (1971). Takeovers: Their Relevance to the Stock Market and the Theory of the Firm. NY: Cambridge University Press.

[105] Singh, A. (1975). Take-overs, Economic Natural Selection and the Theory of the Firm' Economic Journal, Vol. 85, pp. 497-515.

[106] - (1992) : 'Corporate Takeovers' in J Earwell, M Milgate and P Newman (eds), The New Palgrave Dictionary of Money and Finance, MacMillan, London, pp. 480-486.

[107] - (1999): 'Competition Policy, Development and Developing Countries.' Working Paper No 50, ICRIER, New Delhi.

[108] - (2003): The New International Financial Architecture and Competition in Emerging Markets: Empirical Anomalies and Policy Issues' in Ha-Joon Chang (ed), Rethinking Development Economics. Anthem Press, pp. 377-403.

[109] Sinha, A.K., \& Srinivasan, R. (2010), "Valuation and performance consequences of crossborder acquisitions: Indian acquirers and foreign targets". Retrieved from: http://gdex.dk/ofdi10/

[110] Srivastava, R.K. (2012). "The role of brand equity on mergers and acquisition in the pharmaceutical industry: when do firms learn from their merger and acquisition experience?" Journal of Strategy and Management, Vol. 5, No. 3, pp. 266-283. 
[111] Sorensen, Donald.E. (2000). "Characteristics of Merging Firms". Journal of Economics and Business, 52(5), 423-433.

[112] Srivastava, R.K. (2012). "The role of brand equity on mergers and acquisition in the pharmaceutical industry: when do firms learn from their merger and acquisition experience?". Journal of Strategy and Management, Vol. 5, No. 3, pp. 266-283.

[113] Stevens, Donald.L. (1973). "Financial Characteristics of Merged Firms: A Multivariate Analysis". Journal of Financial and Quantitative analysis, 8(2), 149-158.

[114] Sudersanam, (1995). The Essence of Mergers and Acquisitions. NJ: Prentice-Hall.

[115] Sun, S.L., Peng, M.W., Ren, B. \& Yan, D. (2012). "A comparative ownership advantage framework for cross-border M\&As: the rise of Chinese and Indian MNEs". Journal of World Business, Vol. 47, No. 1, pp. 4-16.

[116] Sweezy, paul.M. (1994). The Triumph of Financial Capital. Cornerstone Publications, 46(2), pp. 244-251. DOI:10.14452/MR-046-02-1994-06_1

[117] The Gazette of India (2003): The Competition Act 2002.

[118] Trahan, E.A., \& Shawky, H.A. (1992). "Financial characteristics of acquiring firms: An industry specific approach". Review of Financial Economics, Vol. 1, No. 2, pp. 81-94.

[119] Trautwein, F. (1990). "Merger motives and merger prescriptions". Strategic ManagementJournal, Vol. 11, No. 4, pp. 283-295.

[120] Tsagkanos, A., Georgopoulos, A., \& Siriopoulos, C. (2006). "Predicting Takeover Targets: NewEvidence from a Small Open Economy". International Research Journal of Finance and Economics, No. 4, pp. 183-194.

[121] Thompson, S. (1997). Takeover Activity Among Financial Mutuals: An Analysis of Target Characteristics. Journal of Banking and Finance, Vol. 21, No. 1, pp. 37-53.

[122] Tripathi, V., \& Lamba, A. (2015). Does financial performance improve post cross-border mergerand acquisitions? A detailed study of Indian acquirer firms' financial performance across target economy's development status and financial crisis". Research Journal of Social Science and Management, Vol. 4, No. 9, pp. 325-342.

[123] UNCTAD (1997). Transnational Corporations, Market Structure and Competition Policy. WorldInvestment Report, Geneva.

[124] - (2000): Cross-border Mergers and Acquisitions and Development, World Investment Report, Geneva.

[125] Warf, B. (2003). "Mergers and acquisitions in the telecommunications industry". Growth and Change. Vol. 34, No. 3, pp. 321-344.

[126] Wasserstein, Bruce. (1998). Big Deal. New York: Warner Books.

[127] W.Chu, H. (2006). The strategic determinants of information systems and technology in the success or failure of mergers and acquisitions (Doctoral dissertation). Retrieved from ProQuest Dissertations \& Theses: The Humanities and Social Sciences Collection. UMI Number: 3231939 
Decoding Scale and Size of The Acquired and The Acquirer: An Empirical Analysis

[128] Wang, D., \& Moini, H. (2012). Motives for cross-border mergers and acquisitions: some evidence from Danish firms. Alaborg University, Retrieved from http://vbn.aau.dk/files/74813307/

[129] Weston, J Fred et al. (1996). Mergers, Restructuring, and Corporate Control. Englewood Cliffs, NJ: Prentice-Hall.

[130] Williamson, 0.E. (1968). 'Economics as an Antitrust Defence: The Welfare Trade-offs.' American Economic Review, Vol. 58, No. 1, pp.18-36.

[131] Williamson, 0.E. (2002). 'The Theory of the Firm as Governance Structure: From Choice to Contract'. Journal of Economic Perspectives, Vol. 16, No 3, pp. 171-195.

[132] Worthington, A.C. (2004). "Determinants of Merger and Acquisition Activity in Australian Cooperative Deposit Taking Institutions". Journal of Business Research, Vol. 57, No. 1, pp. 4757.

[133] Wright, M., Filatotchev, I., Hoskisson, R.E., Peng, M.W., Campus, J., \& Campus, M. (2005). "Strategy research in emerging economies: challenging the conventional wisdom". Journal of Management Studies, Vol. 42, No. 1, pp. 1-33.

[134] Zanakis, S.H., \& Zopounidis, C. (1997). "Prediction of Greek Company Takeovers via Multivariate Analysis of Financial Ratios". Journal of the Operational Research Society, 48(7), 678-687.

[135] Zhan, J.X., \& Ozawa, T. (2001). Business Restructuring Asia: Cross-Border M\&As in the Crisis Period. Denmark, Copenhagen Business School Press. 